\title{
神岡製煉所の鉛・亜鉛製錬
}

\author{
正会員高 \\ 皇 \\ 正*
}

\section{Extraction of Lead and Zinc Smelting at Kamioka Smelter}

Tadashi TAKASHIMA

\begin{abstract}
We have endeavored to improve the equipments and the operation in the Kamioka Smelter and Refinery. At the zinc plant we enforced to provide completely each equipments with necessaries, and to produce the high purity zinc slab, zinc die cast alloy - "ZAC"-, and the high purity cadmium pencil. At the lead plant, also we improved the blast furnace and newly established the electric slag settler, the fume collector, scrubber and the zinc recovering from slag system. Furthermore we could produce the high purity lead metal, high purity electrolytic silver and the bismuth metal by means of the improvement of the equipments and the better control of operation.
\end{abstract}

\section{1. 亞鉛製錬部門}

終戦後約 1 年半は操業休止の状態であつたが，昭和 22 年 2 月に至りょうやく操業を再開した。その後今日まで 量的な拡充, 操業法の改善, 品質の向上等, 広範にわた る進歩を遂げ，生座の規模!こおいいて，高純度亜鉛の工業 的生座方式において飛躍的な発展を示した。また自山鉣 の開発進展に伴う良質な原料精鉣の確保に加えて, 自家 発電所の建設による豊富低廉な電力の供給, 操業合理化 による原単位の低下等は生産原価の低減に大きな貢献を 残した。

\section{$1 \cdot 1$ 生産量および設備能力の变遷}

当工場子炤和18年電気亚鉊 $1,000 \mathrm{t} /$ 月を目標之して建 設されたものであるが，操業再開後の炤和 22 年より今日 までの変遷を大別すれば次の通りである。

（1）第 1 段階，昭和22年より 24年まで：一一設備㫆 よび作業員の教育訓練の期間。

この段階は終戦後の休止期間中および戦時中の酷使に よる設備の破損個所整備し，また従来の操業経験を基 にした改造を行い，約半分の設備能力を復旧して電気亚 鉊 $500 \mathrm{t} /$ 月を目標とした。しかしながら食糧事情の逼迫， 資材の入手難に加えて作業員の熟練度の不足（戦時中は 大部分が俘虜, ·季節労務者, 勤奉隊員であつたため終戦 とともに経験者は觜無の状態となつた。)のためここの目 標さえ達成は困難であつた。したがつて設備，作業方法

* 三井金属鉱業株式会社神岡鉱業所技師長
の再検討と作業員の教育訓練に重点がおかれた。

（2）第 2 段階, 昭和 25 年より 28 年まで：一一設備の 量的あるいは併立的拡張の期間。

第 2 段階は残存の設備能力右充分発揮させるため, 生 座目標を電気西鉊 $750 \mathrm{t} /$ 月におき，一方において操業の 合理化, 改善による増座対策を講じ, 他方におるて残余 設備の整備孛行い，各工程間のバランスを検討しなが ら能力の増強を計り，生産の増加に努めた結果，この目 標は容易かつ迅速に達成され，引続き目標 1,000t/月を 目指して進み，昭和26年 4 月に至りこれを達成した。こ の間, 操業方法の改善を計りつつ, 险路打開のため一部 設備の増設によりこの期間の末にはすでに電気两鉛月 産, 最大 1,500 tの能力を備えるに至り，増産の基礎を 固妨るとができた。

（3）第 3 段階, 昭和29年より現在まで：一一設備の 質的あるい:技術的拡張の期間。

生産量の増加に伴い, 既設の自家発電所の能力(合計 最大出力 $9,770 \mathrm{~kW}$ )では不足となり，このため新たに最 第 1 表 年次別亞鉛鉨生產量

\begin{tabular}{l|c}
\hline 年次別 & 生 產 量 \\
\hline 昭和 22 年 & $4,357 \mathrm{t}$ \\
照和 23 年 & $4,884 \mathrm{t}$ \\
照和 24 年 & $7,512 \mathrm{t}$ \\
照和25年 & $10,226 \mathrm{t}$ \\
照和 26 年 & $11,509 \mathrm{t}$ \\
照和 27 年 & $11,982 \mathrm{t}$ \\
照和28年 & $15,344 \mathrm{t}$ \\
照和29年 & $15,753 \mathrm{t}$ \\
昭和 30 年 & $16,121 \mathrm{t}$ \\
\hline
\end{tabular}
大出力 $17,000 \mathrm{~kW}$ の自家発 電所が建設された。このた め電力の需給状態は著しく 好転し，さらに豊水時の電 力利用の目的で增産計画か 唡討された結果，電気亜鉛 月産 $2,000 t$ 友目標しして 拡張工事に請手した。現在 
第 2 表 亞鉛製鍊に和ける設供の变遷

\begin{tabular}{|c|c|c|c|c|c|}
\hline 設 備名称 & 大ささ & $\begin{array}{l}\text { 冡設 } \\
\text { 当初 }\end{array}$ & $\begin{array}{l}\text { 䇫 } 1 \\
\text { 階 } \\
\end{array}$ & 䇥階 & $\begin{array}{l}\text { 筧 } 3 \\
\text { 段階 }\end{array}$ \\
\hline 溶 & $5 \mathrm{~m} \phi \times 3.2 \mathrm{~m}$ & 6台 & 6台 & 8台 & 8台 \\
\hline 熱 交 換 器 & & 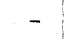 & 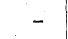 & - & 2台 \\
\hline バートフ淨 & $15 \mathrm{~m} \phi \times 12 \mathrm{~mL}$ & 5台 & 5台 & 7台 & 10 台 \\
\hline 鏼 三清瀞 & 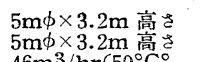 & $\begin{array}{l}\text { 4台 } \\
\text { 3台 }\end{array}$ & $\begin{array}{l}\text { 4台 } \\
\text { 3台 }\end{array}$ & $\begin{array}{l}\text { 6台 } \\
\text { 4台 }\end{array}$ & $\begin{array}{l}\text { 6台 } \\
4 \text { 台 }\end{array}$ \\
\hline 熟 交 換 器 & $\begin{array}{c}46 \mathrm{~m}^{3} / \mathrm{hr}\left(50^{\circ} \mathrm{C}^{\circ}\right. \\
\left.\rightarrow 80^{\circ} \mathrm{C}\right)\end{array}$ & . & - & - & 2台 \\
\hline 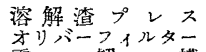 & 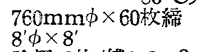 & 2台 & 2台 & 3台 & 2台 \\
\hline $\begin{array}{l}\text { 電 解 } \\
\text { 電 解 }\end{array}$ & 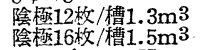 & 288 槽 & 288槽 & 312槽 & 312槽 \\
\hline 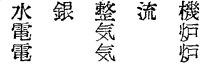 & $\begin{array}{l}5,000 \mathrm{~A} \times 600 \mathrm{~V} \\
80 \mathrm{~kW} \text { 低周波誘導㛐 } \\
540 \mathrm{~kW}\end{array}$ & $\begin{array}{l}5 \text { 台 } \\
5 \text { 台 }\end{array}$ & $\begin{array}{l}\text { 5台 } \\
\text { 5台 }\end{array}$ & $\begin{array}{l}5 \text { 台 } \\
6 \text { 台 }\end{array}$ & $\begin{array}{l}\text { 5台 } \\
(2 \text { 暠) } \\
\text { 1客 }\end{array}$ \\
\hline
\end{tabular}

すでに大部分を完成し，昭和32年春には全部完了の予定 である。この拡張は設備扝よび操業管理の面から, 量的 ないし併立的増加在極力省き，質的あるいは技術的に生 革増強の方策を講した。年次別に生産量おょび設備の变 遷過程老別表に二示文。(第 $1 ， 2$ 表)

\section{$1 \cdot 2$ 主要生産設備について}

ここでは上述第 3 段階の質的拡張について述へる。

（1）溶解能力の增强：一一当所の溶解は単式高温度 溶解法を採用している。電解槽から溶解槽一の帰還尾液

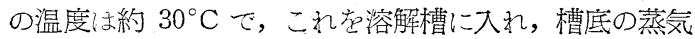
加熱コイルで $50^{\circ} \mathrm{C}$ まで昇温後焼鉱の装大を開始する。 その後は焼鉱の溶解熱て温度は上昇し, 約 $90^{\circ} \mathrm{C}$ 老保つ。 溶解作業 1 サイクルの時間は約 $12 \mathrm{hr}$ で，この内最初の 始液の加蓺時間が約 $4 \mathrm{hr}$ ，すなわち約 3 分の 1 に相当す る。この時間を節減して溶解能力を高めるため, 電解尾 液な溶解槽に戻方経路に熱交換器を設置した。この結果 溶解槽中の溶液の滞留時間が著しく短縮され, 能力の増 強をもたらした。本設请の仕様抢よひ操業成績は別表

（第3 表）の通りであるが，な抢装置の特長として次の ような諸点が挙げられる。

a. 溶解盙中の液の滞留時間を短縮でき, 能力が増加 ナる。

b. 溶解槽の増設に比し設備費が極めて安い。

c. 設備の据付面積がさくてよい。

d. 熱効率が高く，ドレーンの回収利用が簡単て確寒 にできる。などである。

（2）濾過能力の增强：一一溶解液の濾過にはバート フィルターを使用している。本機は $\phi 1.5 \mathrm{~m} ， \mathrm{~L} 12 \mathrm{~m}$ の

第 3 表 溶解始液加熱用熱恋換器

\begin{tabular}{|c|c|}
\hline 任様 & \\
\hline 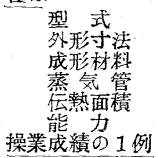 & 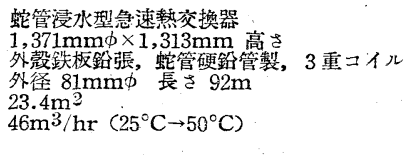 \\
\hline 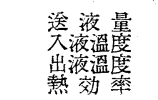 & $\begin{array}{l}58.5 \mathrm{~m}^{3} / \mathrm{hr} \\
27^{\circ} \mathrm{C} \\
47^{\circ} \mathrm{C} \\
77 \%\end{array}$ \\
\hline
\end{tabular}

第 4 表 滤 材 $の$ 变 僊

\begin{tabular}{|c|c|c|c|}
\hline 绱 & 最初の濾材 & 第1 回改造 & 第 2 回改造 \\
\hline 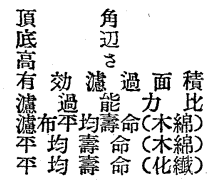 & $\begin{array}{l}90^{\circ} \mathrm{L} \\
235 \mathrm{~mm} \\
152 \mathrm{~mm} \\
77.8 \mathrm{~m}^{2} \\
100 \\
100 \text { 回 } \\
-\end{array}$ & $\begin{array}{l}45^{\circ} \mathrm{L} \\
210 \mathrm{~mm} \\
288 \mathrm{~mm}^{2} \\
114.2 \mathrm{~m}^{2} \\
180(100) \\
100 \text { 回 } \\
- \\
-\end{array}$ & $\begin{array}{l}45^{\circ} \mathrm{L} \\
210 \mathrm{~mm} \\
256 \mathrm{~mm}^{2} \\
100.0 \mathrm{~m}^{2} \\
288(160) \\
200 \text { 回 } \\
200 \text { 回 } \\
380 \text { 回 }\end{array}$ \\
\hline
\end{tabular}

内面銅板ライニング鉄板製シリンダーよりなり，内部に 長さ約 $6 \mathrm{~m}$, 頂角 $90^{\circ}$ の三角形木製濾材がシリンダー中 央の濾液抽出口の両側に合計 32 本締付けてある。最初の 有効濾過面積は 1 基当り $77.8 \mathrm{~m}^{2}$ であつたが，濾過能力 増加のため頂角を $45^{\circ}$ と，かつ濾材の高さを高めて有 効濾過面積を增加し， 1 基当り $114.2 \mathrm{~m}^{2}$ とした。さら に頂角の変更による濾布の耐久度低下を防ぐため, 濾過 面積存 $100 \mathrm{~m}^{2}$ とし，第1圀のらうに改造した。また木 綿濾布の代りに化繊濾布存使用し，この形に逐次各濾過 器を改造した結果, 能力, 濾布の寿命々も著しく改善さ れ, 濾過器の増設を最小限にとどめることができた。

（3）清淨能力の增强: 一一当所の清浄は亜吪酸, 亚 鉛未による第 1 回清浄により $\mathrm{Co}, \mathrm{Cu}$ を除去し,さら に亜鉛末単味による第 2 回清浄により Cd を完全に除去 する。いわゆる二段清浄法である。この場合, 第 1 回清 浄は $80^{\circ} \mathrm{C}$ 以上が好ましいが, 濾液を受入れる際の液温 は 65〜 70C であるから，これを再加熱する必要があ

最初の滤材

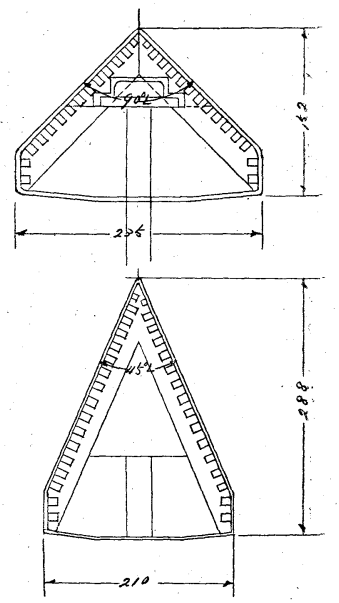

第 2 回改浩滤材

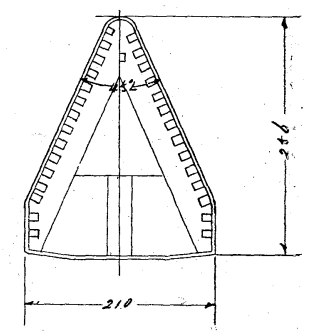

第1図 バットフィルター滤材の变遷 
る。このため清浄槽の槽底の銅製蒸気加熱コイルで温度 存高める方法をとつていたが，溶解之同様極めて熱効率 が低く長時間を要した。すなわち 1 サイクル $11 \mathrm{hr}$ のう ち, 加温に要する時間は $6.5 \mathrm{hr}$ に及ぶ。したがつてバー トフイルター濾液をあらかしめ加熱するように,この経 路に熱交換器を設備し, 清浄槽中の溶液の滞留時間を短 縮せしめることにより清浄能力の増強を計つた。この利 点は前述と同様であるが，仕様および成績を第 5 表に示 †。

第 5 表 第 1 清淨始液加熱用熱垐換器

\begin{tabular}{|c|c|}
\hline \multirow{2}{*}{ 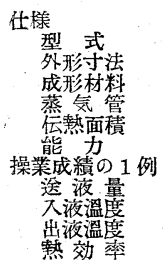 } & 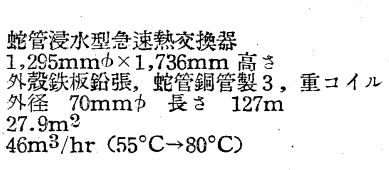 \\
\hline & $\begin{array}{l}46.5 \mathrm{~m}^{3} / \mathrm{hr} \\
49^{\circ} \mathrm{C} . \\
78.5^{\circ} \mathrm{C} \\
98 \%\end{array}$ \\
\hline
\end{tabular}

（4）溶解渣処理能力の增强：一一溶解残渣の処理設 備は設計時には二段溶解法に基いて複雑な系統になつて いたがこれを極力単純化するため徹底的に改造した。 改造前後に括沙る采統抢よび設備の概要老第 2 図に示 す。改造に当つて考慮された主要な点は，

a. フィルタープレスを廃し, シックナー, オリバー フィルター方式とし，人手を省く。

b.シックナー，ポンプあるいは配管類の “閉塞” の 原因となる細粒は従来㳳降樋て除去していたが，新たに 混式サイクロンを採用して“スピゴット”として除き， その悪影響を排除しつつ同時に捕集細粒はオリバーフィ ルターの皿に遵き，濾過能率の向上を計る。

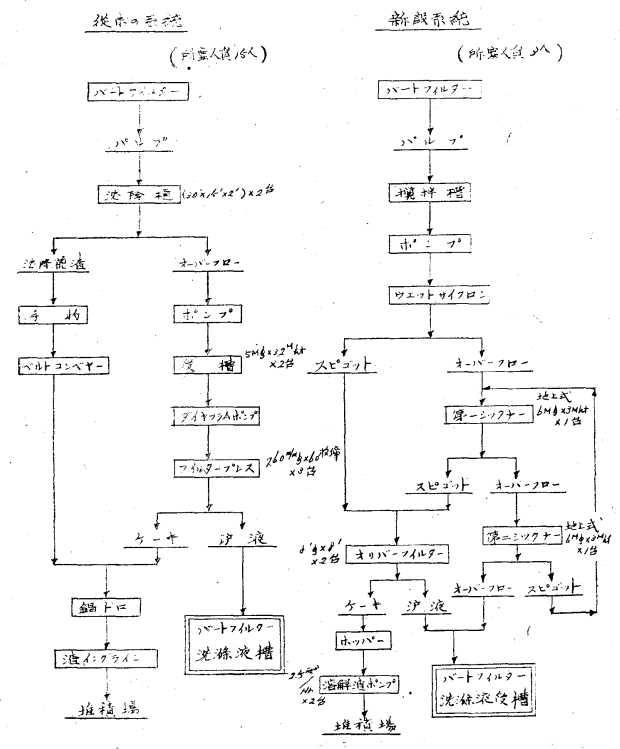

第 2 図溶解渣迈理系統の变遷

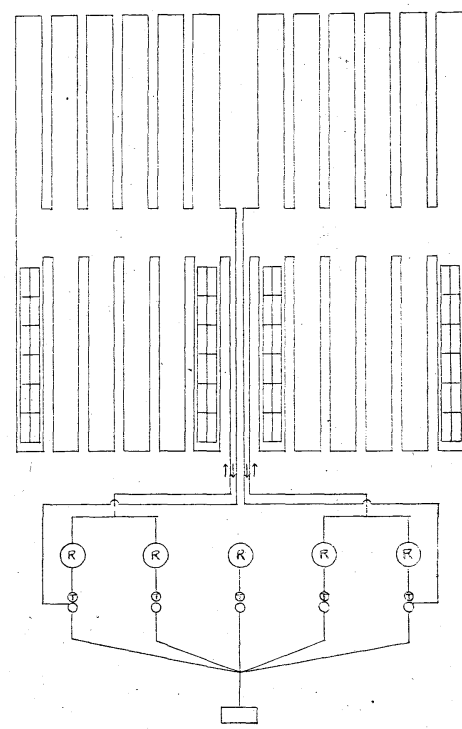

$\mathrm{R}:$ 水銀

整流機

$3,000 \mathrm{kVA}$

$(600 \mathrm{~V} \times$

$5,000 \mathrm{~A})$

第 3 図

電解槽

結線囝

c. シックテーは地上式とし，維持抢よび管理に便な らしめるとともに小容量のもの在 2 基直列に使用して建 設費を節減する。

d. 濾過渣は椬輸送ポンプを採用することにより全く 人力を要せずに直接堆積場に送る。

（5）電解能力の增强：一一電解槽は当初炻器製のも のが 6 槽カスケードに配列され，144 槽ずつ 2 系統, 合 計 288 槽を有し, 144 槽ごとに容量 $3,000 \mathrm{~kW}(5,000 \mathrm{~A} \times$ $600 \mathrm{~V})$ の水銀整流器 2 基が併列に配置され，なお共通 の予備として別に 1 基在備えていた。(第3図参照) え の後24槽を増設して 156 槽ずつ 2 系統，合計 312 槽とな つたが，増産の目的で通電電流も漸次高くなり，この間 極板用ナイフスイッテを $3 \mathrm{~mm}$ 厚より $6 \mathrm{~mm}$ 厚に変更, 槽内冷却設備の強化に上る液温上昇の防上, 電解槽整㣁 サイクルの計画化等の対策実施に努めた。この方法によ り生産は著しく増加したが，電解における質的な面，す なわち電流能率，析離覀鉛中の鉛含有量等に打いてこれ らの対策にも限度があり，通電電流を最高 $7,500 \mathrm{~A} に$ に抑 えざる在得なかつた。したがつてその後の計画としては 電解槽の配列方式, 槽数, 整流器との祭係等は従前のま まとし，水銀整流器の最大容量たる 10,000A 在通電可

第 6 表 新旧電解槽比較表

\begin{tabular}{|c|c|c|}
\hline 要 & 設 & 旧 \\
\hline 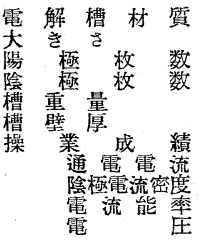 & $\begin{array}{c}\text { 鉄板製硬ゴ么張 } \\
1.5 \mathrm{~m} 3 \\
17 \text { 枚/槽 } \\
161 " \\
610 \mathrm{~kg} \\
16 \mathrm{~mm} \\
\\
9,500 \mathrm{~A} \\
540 \mathrm{~A} / \mathrm{m}^{2} \\
94.5 \% \\
3.45 \mathrm{~V}\end{array}$ & 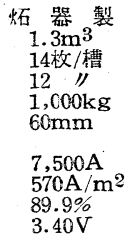 \\
\hline
\end{tabular}


能のようにする一方, 新型電解槽を設計購入して逐次更 新するとともに，通電中電解槽の全面的点検ができる うに基礎の改修を行うなどにより，生産量の增加，操業 成績の向上の両面において改善を計つた。

新旧両電解槽の比較は第 6 表の通りである。

（6）螾鋳能力の增强：一一従来 $80 \mathrm{~kW}$ 低周波誘導 炉, (Ajax Wyatt 炉) 6 基により 1 日当り $60 \sim 62$ tの 型覀鉛を生産していたが，さらに増産に対してこの型の 設備を増設することは据付面積打よび建家を增し，作業 人員の比例的増加を招き，かつまた設備費も比較的多額 に上るため甚だしく不利と考えられた。このため最終的 には現在の炉は大部分他に転用することとし，新たにド ィッ Demag 社の大型低周波諗導炬 1 基を輸入し，設置 した。

この炬は鉄板製外殼で，炉槽は断熱および耐火徚瓦で 内張され，熔態两鉛の接触する炬槽各部および熔融部は 特殊なスタンプマスで捣き固められ，熔態覀鉛の浸透が 完全に防止されている。炉内には約 $25 \mathrm{t}$ の愹融亚鉊を 保有する共通浴古有し，90kW の炉用トランス 4 基, $180 \mathrm{~kW}$ の炉用ダブルトランス 1 基が併用され，これの 通電に上り加熱熔融されるものて低周波誘導炑の利点之 反射炉の利点を兼坟備えている。製品の均一性を高め, 作業人員を大巾に減じ得る外，ドロスの生成率が低く， 電力消費量が少ないなどにより愹鋳費を著しく低下する ことができる。仕様の概略仙次の通りである。
保融能力

1 日熔解能力

\section{電気容量}

力率
$25 \mathrm{t}$

公称 $80 \mathrm{t}$

最大 $96 \mathrm{t}$

$800 \mathrm{kVA}(540 \mathrm{~kW})$

0.66

\section{$1 \cdot 3$ 技術的改善について}

（1）高純度亞鉛の生産：一一終戦後覀鉛製鍊に課せ られた問題は製品品位の向上，すなわち高純度互鉛の生 産である。ダイキャスト方面への亜鉊の利用が急速に増 加し，従来主要な用途であつた亜鉊鍍鉄板抢よび伸銅品 等の用途から独立的用途一の転換策として関心が高ま りしかもダイキャスト用覀鉊は特に高純度であること が要求されたからである。神岡では再開当時より この方面の研究に着手し，すでに昭和23年には一 部, い为ゆる four nine の産出をみたが，さら にその後生産量の増加のため陰極電流密度の上 昇，そえに伴う電解槽温度の上昇等，亜鉊の純度 向上とは相反する要素が増加したため，一時高純 度品の生産は低下を余儀なくされた。その後この 相反する両面を同時に達成するための研究，努力 が続けられ，遂にこれを確立することができ，生 産量の増大, 高純度亜鉛の生産を兼亦実施しつつ

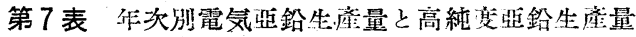
及び比率

\begin{tabular}{|c|c|c|c|}
\hline 年 次 別 & 全生產量 & 高純度晋鉛生宸量 & 此 \\
\hline $\begin{array}{l}\text { 照和 } 22 \text { 年 } \\
\text { 照和 } 23 \text { 年 } \\
\text { 照和 } 24 \text { 年 } \\
\text { 照和 } 25 \text { 年 } \\
\text { 照和 } 26 \text { 年 } \\
\text { 照和 } 27 \text { 年 } \\
\text { 照和 } 28 \text { 年 } \\
\text { 照和 } 29 \text { 年 } \\
\text { 和 } 30 \text { 年 }\end{array}$ & $\begin{array}{r}4,357 \mathrm{t} \\
4,884 \mathrm{t} \\
7,512 \mathrm{t} \\
10,226 \mathrm{t} \\
11,509 \mathrm{t} \\
11,982 \mathrm{t} \\
15,344 \mathrm{t} \\
15,753 \mathrm{t} \\
16,121 \mathrm{t}\end{array}$ & $\begin{array}{c}0 \\
1,705 \mathrm{t} \\
4,717 \mathrm{t} \\
4,410 \mathrm{t} \\
1,341 \mathrm{t} \\
5,568 \mathrm{t} \\
14,204 \mathrm{t} \\
15,508 \mathrm{t} \\
15,181 \mathrm{t}\end{array}$ & $\begin{array}{l}0 \% \\
34.9 \\
62.8 \\
43.1 \\
11.7 \\
42.9 \\
92.6 \\
98.5 \\
94.2\end{array}$ \\
\hline
\end{tabular}

今日に至つている。

（2）苂イキャスト合金 (ZAC) 工場の建設：一一高 純度西鉛の生泩が軌道にのり，これと同時にこの種高純 度亜鉛を主原料とするがイキャス卜合金の工業的製造が 企図された。これに先立つて当社東京研究所て鋭意研究 が進められたが，逐次問題点が解明せられ，昭和28年充 分な検尌を経て神岡にダィキャス卜合金製造工場が建設 された。最初は \#300 黒鉛ルッ示を使用する $35 \mathrm{~kW}$ 電 熟炉 3 基を設置し，生産量月蓙 $100 \mathrm{t}$ t目標として操業 を始めたが, その後需要の進展に伴い, 操業方法, 設備 に改善を重㱛, 傍らルッ示の研究を進めて製造能力の増 強に努め，さらに䀡和 30 年末に 1 基増設を行い，合計 4 炉とし現在月産 $500 t$ の能力龙備えるに至つた。

また合金の種類も ZAC \#1 を始め, ZAC \#2, ZAS, ZAC-T その他数種類に及んでいる。

（3）高純度カドミウムの生産；一一前述のように亜 鉛については早くから高純度品の研究も進み, また製品 として満足す心゙きものが大量に生産されたが，一方カド ミウムについてはいまたにに一般に高純度品の要望も少な くしたがつて研究もあ宁り進んでいなかつた。しかし 近年漸くこの分野でも高純度品が注目されるに至り，当 所でも昭和29年に操業方法を変更し，累次の改善を経て 高純度品の生産を開始した。その一つの系統は主として 清浄部門之電解部門に処理方浩の改良を加えたもので, 従来の方法と比へて経費的にも，能力的にも何等制約さ れず品位の向上が可能となつた。

（4）その他：一一全般に技術面，作業面で検討を加 え, 合理化を進めた結果, 採収率, 原単位, 人員等の面 で逐次成績!上上昇した。この内主なるものを列挙すれば

第 8 表 採收率及び主要原単位の变湮

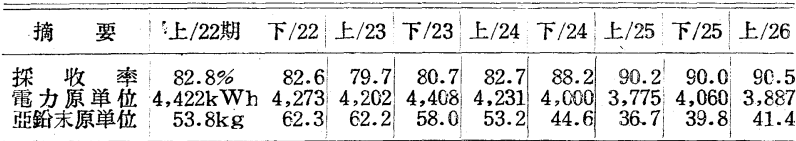

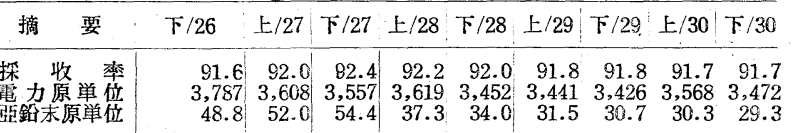


第 8 表の通りである。

以上極攺て概略であるが過去 10 年間 の変遷を述へた。現在着手しているも の，ないし今後に残された問題も多尔 あるが，例元ば特殊の用途をもつ超高 純度覀鉛の製造, 第 1 清浄渣上り銅, コバルト，その他の有価金属の回収， 鉣滓（溶解渣）処理の発展，原料抢尔 び製品類の運搬方法の改善等，生産規 模が増大するにつれて，これ等は早急 に解決されな沙ればならなものと考 えている。

\section{2. 鉛製錬部門}

終戦より昭和 24 年まで老復興期, そ の後昭和28年までを操業方法の改善

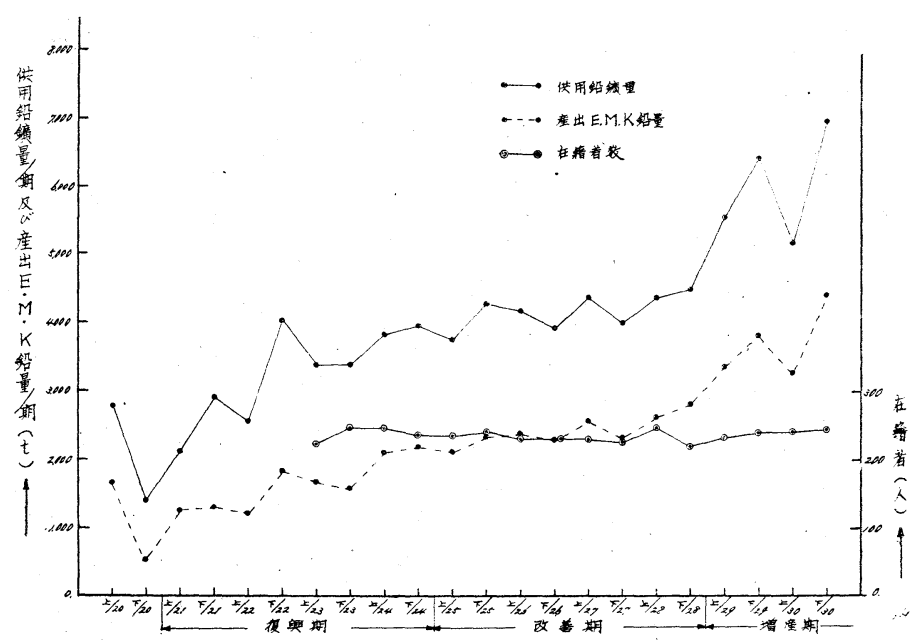

第 4 図期別供用鉛鉣量, 産出 $\mathrm{EMK}$ 鉛量及ど在籍者数
期, さらに最近の 2 年間を增㡾期と分類する。この間に おける变遷は次の通りである。

\section{$2 \cdot 1$ 設借の改善および新設}

（1）電気鍊鍰炉の設置：一一熔鉣炉鍰の処理のため 従来クリーナー炬を操業していたが,ささらに能率よく操 業の容易な鍊鍰炬（三相エルー式， $150 \mathrm{kVA} \times 2$ ) を採用 し，好成績を収めた。

（2）熔鉱炉の改造 : 一一鉊鉱処理量の増加に伴い， 従来の 60t/日ピルツ式丸型炉 2 基のうち 1 基を 100t/日 容量の棈円形に改造し, 昭和28年 6 月より操業を開始し た。改造炉は丸炉に比へて能力に抢いて約 $90 \%$ 增となり 鉊採収率も上昇した。現在鉛の通計愹錬採収率は95\%を 遙かに超えている。

（3）收槪設備の增强：一一鉛鉱焼結用 DL工場に打 ける飛散粉魁の除去抢よび回収の目的で二段式サイクロ ンおくび排風機 $\left(300 \mathrm{~m}^{\mathrm{i}} / \mathrm{min} \times 40 \mathrm{~kW}\right)$ を新設し，1.5t/日 の鉛塵を回收するに至つた。工場内の雾囲気もこれによ り著しく改善された。

(4) 排煙処理用スクラバーの新設 : 一一愹銥炉排ガ スはコットレル収麇機を経て共通煙道に入れていたが， ガス量の増力加にり压力損失を增大し，炬の能力が充分 に発揮できないためコットレル出口に散水式無充填型 のスクラバー（鉛板製塔で選鉣場廃水を注入する）を設 け，焙焼がスと別系統にした。

（5）鉱浑処理設借の新設：一一愹鉱炉の鍰中には 9 10\% の西鉛が含まれており，回収法につき長い間試 験研究を行つた結果, 電気炉法を採用することとなり, 昭和28年10月より操業を開始した。渴水期には電力が不 足するが通常蒸溜两鉛を毎月 $50 \mathrm{t}$ 程度回収し得て, 操 業状態は好調である。

\section{$2 \cdot 2$ 操業方法の改善}

（1）熔鉱炬操業法の变更：一一焼結部門におお揢 剤の加調量を極力少なくして高鉛焼結塊を得, 愹鉣炉の 出鍰率を最小とする操業法を確立した。この対策は高品 位鉊精鉣の処理に対して設備の能力を高め, 実収率を上 昇し，䖫鍊費老低減する上に役立つている。

（2）鉛電解條件の管理 : 一一神岡の粗鉛は他に比し $\mathrm{Bi}$ および $\mathrm{Ag}$ が極めて高いため(Bi0.7〜0.8\%, Ag 0.4 〜 $0.5 \%$ ), 鉛電解の條件は特に考慮を払う必要がある。 長期にわたる試験操業の結果, 陽極中の不純物量に态し て電解液の組成, 温度等に管理基準を設け, 日常これを

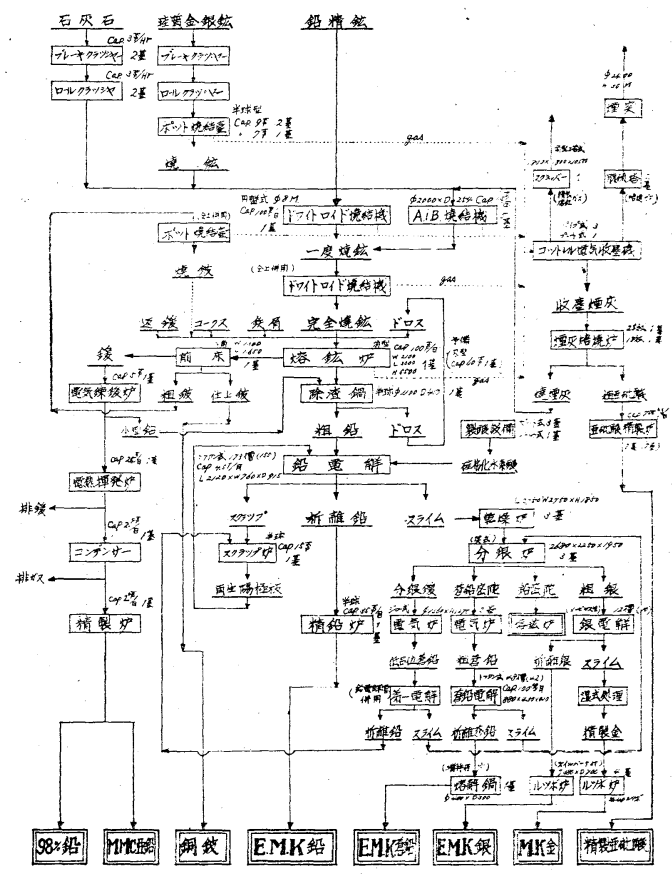

第 5 図 鉛製鍊㙅業系統図 
調節玄ることにより析離鉊の品位を極めて狭い範囲に抑 えることがてきた。析離鉊を単に愹解したのみで得られ る鉊地金の品位は常に 99.995\% を超えている。

(3) 高純度電気銀の生産：一一従来主として Bi の 混入により神岡座電気銀にはいささか難色があつたが, 分銀工程の管理 (炉内雾国気の規正, 酸化剂の使用等), 之銀電解に抢沙る諸條件 (隔膜, Ag イオン対酸濃度)， の規正により製品の品位は著しく上昇し，かつ变動が少 なくなり，99.997〜99.998\% を維持するに至つた。
（4）蒼鉛精製法の改艮：一一電解で得られる析離蒼 鉛の精製熔鋳工程て硫黄末抢よび节性ソーダを用い，こ れと鋳造温度等との相関を見究実施に移した結果，製 品の品位は 99.97〜99.98\% を確保し，精製費も低下し た。

以上鉛部門は個々の改善虏累積しつつ操業度を高めて 現在に至つているか今後運搬の合理化を重点として計画 を進めたいと考无ている。終戦後, 今日に至る生産量の 変遷克第 4 図に，現状の処理系統を第 5 図に示す。

\section{$\mathbf{K N}$ 式水分検定器について}

物質内含有水分の迅速測定は製造 工程中に打引る品質管理上重要であ るのみならず，原料正で製品等につ いてもその重要性は一般に認識され つつ有る。

ここに記載する $\mathrm{KN}$ 式水分检定器 に鉣石，石晨，コーク六等に最適で 鉣石製鍊，石孷コークス及び製鉄関 係に使用されている。

この構成は赤外線電䟵の輻射土ネ ルギーによつて試料中の水分を迅速 に乾燥し，その重量変化を自動的に 電気式天科によつて指示評に指示也
しめ，乙の試料の水分を直続子る。 赤外線エネルギーは乾燥に対して は最も能率的である。この赤外線電 球によつて試料が照射を受汁ると含 有水分は直らに蒸発告開始する。そ れに比例して水分指示の指針が目盛 盤上の水分\%在指示文る様になつて いる。

なお，赤外線照射温度の調節はス シイダワクによつて赤外線シンプ供 給電圧の調節によつて行われる。

試料の乾燥室と天科室は隔離され ておつて乾燥室の熱は天科部に伝わ
らないので天科は熱に対して無影響 となる。 $\mathrm{KN}$ 式水分検定器には数種 の型式が有り試料の量は $1 \mathrm{~kg} か ら 5$ $\mathrm{g}$ 迄に分れている。

米国に抢ける最近の水分測定には 熱風乾燥と天科を組合せたものが有 子。

ドィツに抢いては鉱石関係には赤 外線電球による乾燥方式を用いてい る。

天科はいずれも光学的目盛指示々 なつている。

（日本治金化学工業提供）
西独アスカニア社においてはこの 種光学器械の他に自動制御装置のメ 一カーとして世界的に有名である。

このポケットパイロメーターは昭 和30年以来日本に輸大され节販され ている全輻射高温計で $600^{\circ} \mathrm{C} \sim 2400$ ${ }^{\circ} \mathrm{C}$ の温度測定に適している。

構成は温度のトレーサーとして小 さなバィメタルを使用し，その一端 に指示器とつけてあつてそれが温度 の影響によつて自動的に作動し温度 指示在行うようになつている。この バィメタルは人工的に温度変化によ り作動させていてその性能墲限に 不変であると称している。

このバィメタルは現在のところわ が国では製作出来ない。

この指示器は外径約 $2 \frac{1}{3} /$ in の収斂 レンズとこの焦点距離に相当する
$6 x / 2$ in の長さの望遠鏡型容器にセッ 下されている。反対側には接眼鏡が 有つてこれで観測者は目盛盤上の指 針の指示と被測定物を同時に見られ るようになつている。

な打目盛が示す温度以外の寒暖に よるいがる夾雑作用をも避访るた めにこのバィメタルは第二の合金製 シセンによつて修整されている。そ のため, 指示目盛上の計測時以前の いかなる数值の䛊謬も，接眼鏡の頭 部でこの第二のシセンを备すことに より修整出来る。

特滗す心゙き事は

使用法が極めて簡単で, 維持買は
全く不要である。手で動かして操作 するのでないから損傷する部分は全 くない。加元て従来の固定式輻射高 温棓とは異り観測距離の点が程めて 合理的に使用し易く出来ているので 如何なる角度から観測することも出 来ることである。

如何に危険な現場でも重量が軽く 小さいので使用簡便であり，測定者 の個人䛊差は無い。

現在米国その他各国に輸出されて いる。

金属熔解炉，楒瓦焼成炉，ルツ示 炉，焼入炉等に最適である。

（日本治金化学工業提供）
西独アスカニアヴエルケ社製 ポケットパイロメーターにっいて 